\title{
Assessment of the health status of the Sidi R'Ghies forest, Oum El Bouaghi, north-east Algerian
}

\author{
MALIKA RACHED-KANOUNI ${ }^{1}$, ALIA ZERROUKI ${ }^{1}$, MAROUA LAHMAR ${ }^{1}$, AMINA BELDJAZIA ${ }^{2, \bullet}$, \\ KARIMA KARA ${ }^{3}$, LABED ABABSA ${ }^{1}$ \\ ${ }^{1}$ Department of Natural and Life Sciences, Faculty of Exact Sciences and Natural and Life Sciences, University of Larbi Ben M'Hidi Oum El Bouaghi. \\ ${ }^{1}$ st November 1954, Oum El Bouaghi 04000, Algeria \\ ${ }^{2}$ Departmnent of Plant Biology and Ecology, Faculty of Nature and Life Sciences, University of Ferhat Abbas Setif 1. El Bez, Setif 19000, Algeria \\ vemail: beldjaziaamina@yahoo.fr \\ ${ }^{3}$ Department of Biology and Plant Ecology, Faculty of Nature and Life Sciences, University of Mentouri Constantine 1. BP, 325 Ain el Bey road, 25017, \\ Algeria
}

Manuscript received: 28 February 2020. Revision accepted: 13 April 2020.

\begin{abstract}
Rached-Kanouni M, Zerrouki A, Lahmar M, Beldjazia A, Kara K, Ababsa. 2020. Assessment of the health status of the Sidi R'Ghies forest, Oum El Bouaghi, north-east Algerian. Biodiversitas 21: 1980-1988. In recent decades, the forest of Sidi R'Ghies has been degraded by human activity. The establishment of the state of the massif by a diagnosis on different forest plots is part of a project of monitoring and silvicultural management. The purpose of this study is to assess the health status of the Sidi R'Ghies forest. The methodology used was the visual assessment of the tree crown of the dominant species (i.e. Aleppo pine and holm oak) according to the protocols DEPEFEU, DEPERIS, and ICP Forests. These protocols were selected for adoption based on field observations and their applicability in record time. The results obtained indicate that the health status of the trees within the studied plots is declining. The DEPEFEU value index shows an average of 2.20 for Aleppo pine and 1.95 for holm oak while the DEPERIS has an average level of 4.56 in Aleppo pine and 3.07 in holm oak. ICP Forests has also contributed to providing clearer information on the consequences of this health situation by deducting an average visibility rate of 1.24 and 1.63 ; social status of 2.17 and 2.11 and competition of 1.71 and 2.49 for Aleppo pine and holm oak respectively. In general, the health status of the tree crown is average and almost adapted to the environmental conditions. In contrast, the carrying capacity of biodiversity is low and needs to be improved.
\end{abstract}

Keywords: DEPEFEU, DEPERIS, ICP forests, Health status, Sidi R'Ghies

\section{INTRODUCTION}

The importance of forests has no longer to be demonstrated from an economic, ecological, aesthetic or cultural point of view (Keenan et al. 2015). In an alarming context of climate change and drastic biodiversity loss, the need to sustain the ecosystem services provided by forest ecosystems is essential, as such great care must be taken to preserve them. One of key strategies for forest preservation is by monitoring forest areas in order to assess their health and try to identify the precise causes of any decline (Keča et al. 2016).

Decline as a term of symptomatology is defined as a set of anomalies perceptible to the eye in the field (Lindner et al. 2010; Denman et al. 2014). These anomalies correspond to the idea of an overall deterioration in the health of the tree which can be seen by the reduction in the quality and quantity of foliage or shoots, but especially mortality of existing organs (twigs in particular). The term also includes a certain idea of evolution over time that reflects the fact that the natural outcome for the dying tree is considered problematic but not necessarily fatal (Woo 2009). Decay, which is in fact based on a set of symptoms that vary from case to case, does not in itself imply any particular causes and should not a priori be considered as a disease. Decay is always a complex phenomenon that can be analyzed using the following criteria of different response indicators: biochemical response through analysis of modifications carbon reserves (Galiano et al. 2012; Michelot et al. 2012; Rosas et al. 2013; Gerard and Bréda 2014); anatomical response by the cambium and growth losses (Gricar et al. 2013; Gricar et al. 2014; Helama et al. 2014; Tulik 2014); morphological response through changes in crown architecture and leaf losses (Lee et al. 2014).

Climate is one of the variables that influence forests health and disturbance regimes. According to the third IPCC report, the global average surface air temperature is projected to increase by 1.4 to $5.8^{\circ} \mathrm{C}$ by 2100 , with significant impacts on all elements of the global climate system (Hicke et al. 2006). The impacts of climate change on forest ecosystems will vary by region and will depend on several factors, including species composition, environmental conditions, and local microclimate. Changing moisture conditions and disturbance regimes are a key concern for the forest sector (Petit et al. 2005). Warming temperatures are likely to increase the frequency of forest fires and expand areas of forest pest activity. Indeed, increased disturbances such as insect infestations (Moorcroft et al. 2006) and fires can lead to rapid structural and functional changes in forests (Thuiller et al. 2004).

During the last few decades, the dieback of forest trees, and more specifically oaks, has raised many concerns 
among managers (Martinez-Vilalta et al. 2012; Gustafson and Sturtevant 2013; Niu et al. 2014; Vitale et al. 2014; Eickenscheidt and Wellbrock 2014; Cater 2015), and understanding of the underlying causes of this phenomenon has been the subject of numerous studies (Thomas et al. 2002; Galiano et al. 2012; Lee et al. 2014; Tulik 2014). These works have very often concluded on the importance of drought and its interactions with abiotic factors (e.g. soil fertility, temperature) and/or biotic conditions (e.g. floristic composition and structure).

In Mediterranean regions, many outbreaks of dieback of woodlands and reforestation stands have been reported in recent years. Among the main forest species affected by the phenomenon are the Atlas cedar in Morocco and Algeria (Terrab et al. 2006; Linares et al. 2011; Klein et al. 2013; Belloula and Beghami 2018), several pine species in Morocco and France (Thabeet et al. 2009; Girard et al. 2011; Gricar et al. 2013; Morcillo et al. 2019), certain oak species (cork oak) in France, Spain, Portugal, Morocco and Algeria (Rached-Kanouni et al. 2012; Touhami et al. 2019), beech and fir in France. The estimation of these symptoms is assessed by the use of the Hardwood Dieback Protocol DEPEFEU, developed by the Department of Forest Health (Nageleisen 2011). This protocol allows the assessment of the condition of hardwood and coniferous crown trees on several criteria. The main ones are crown transparency, mortality of perennial organs (branches) and leaf mass distribution (Delaporte 2017).

Algerian forests, in addition to the effects of climate change, will be stressed by other changes related to human pressure (Raffa et al. 2008). In this context, it is therefore interesting to question the current state of health of the Sidi R'Ghies forest in Oum El Bouaghi, north-east Algeria which made up of a set of silvicultural species (deciduous and coniferous). Is the health balance different for hardwood (holm oak) and softwood (Aleppo pine) stands? What could be the causes and repercussions of a decline in terms of functionality at the tree level?

Our study was conducted at two spatial scales. At the plot level, the main objective was to assess the state of health of the Sidi R'Ghies forest on a set of hardwood and softwood plots based on different indicators of decline and biodiversity. The second objective was to determine the local causes of dieback and its functional consequences at the tree level. To do this, dendrometric analyses combined with visual observation of some symptoms on branches and canopies were undertaken.

\section{MATERIALS AND METHODS}

\section{Study area}

The forest of Djebel Sidi R'Ghies is located in the northern part of the city of Oum El Bouaghi, north-east Algeria. The geographic coordinates are $35^{\circ} 54^{\prime} 42^{\prime \prime} \mathrm{N}$ and $7^{\circ} 7^{\prime} 52^{\prime \prime}$ E. Its altitude is about $1635 \mathrm{~m}$ above sea level (Figure 1). The area extent of the Sidi R'Ghies forest is estimated 3106 ha with a perimeter of $28.66 \mathrm{~km}$. The climate is semi-arid with cool winter, with an average annual rainfall of $378 \mathrm{~mm}$ and an average annual temperature of $25^{\circ} \mathrm{C}$.

The forest of Sidi R'Ghies is composed by natural vegetation of native species, including holm oak (Quercus ilex), the juniper of Phoenicia (Juniperus phoenicea), the oxycedre (Juniperus oxycedrus), the Atlas pistachio tree (Pistacia atlantica) and the wild olive tree (Olea europaea), and planted stands with the main species include the Aleppo pine (Pinus halepensis) accompanied by Cupressus sempervirens, Acacia cyanophylla, and Eucalyptus camaldulensis.

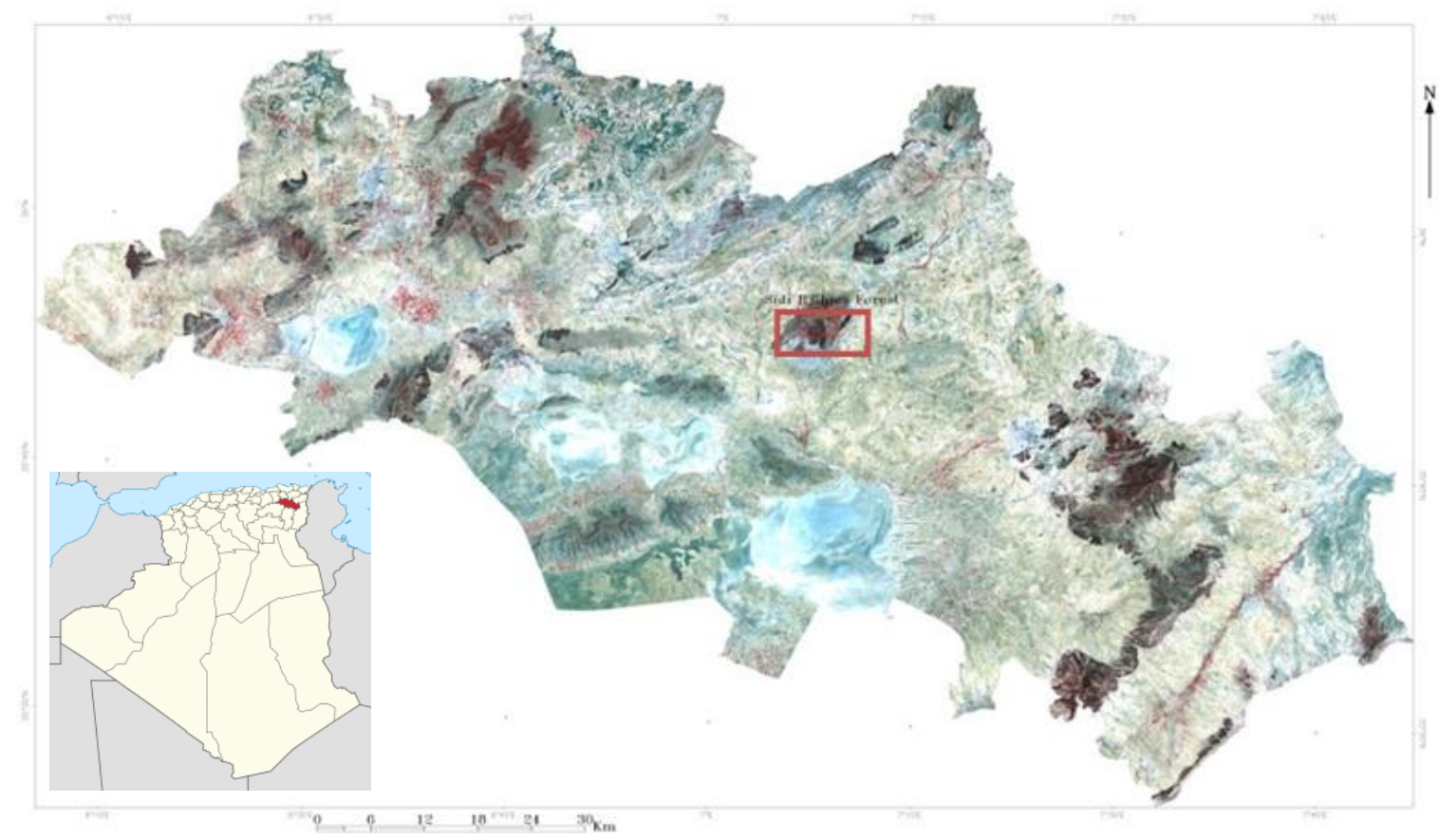

Figure 1. The map of study area over pseudo infrared color composition obtained from Landsat 8 satellite processed with ENVI 5.1 software 
Until now, Sidi R'Ghies forest does not have a permanent observation system of the health of the stands. However, this forest presents a certain vulnerability due to the proximity to Oum El Bouaghi city (atmospheric pollution, important frequentation), particular edaphic conditions (poor soils: hard limestone and dolomite, hard alluvium and sand etc.), climatic (hot and dry in summer, and cool in winter), the nature of the forest stands (i.e. specific composition dominated by holm oak and Aleppo pine with unbalanced age structure) and insects (Thaumetopoea pityocampa).

\section{Methods}

Delimitation of parcels of land

Eight plots with an equivalent area of $1000 \mathrm{~m}^{2}(50 \mathrm{~m} x$ $20 \mathrm{~m}$ ) were delimited in order to obtain a representative sample of the entire forest. Aleppo pine was the dominant forest species in the first group of plots (P1, P2, P3 and $\mathrm{P} 4)$, while holm oak was the main species in the second group of plots (P5, P6, P7, and P8). All trees within the parcels were recorded. Dendrometric measurements and visual observations were conducted during the 2019 summer season (July-August).

\section{Dendrometric measurements}

The biomass of a forest is a good indicator of its productivity and provides information on its health status. In this study, biomass estimation was limited to aboveground biomass. In order to evaluate this biomass, two parameters were recorded in the field, i.e. total height $(\mathrm{Ht})$ and diameter at breast height $(\mathrm{DBH}$, i.e. $1.30 \mathrm{~m}$ from the ground) for all trees with a circumference greater than $7.5 \mathrm{~cm}$. The slenderness coefficient of a tree (SC) is the ratio between the total height $(\mathrm{Ht})$ and the diameter (D) which reflects the stability of a forest stand or an isolated tree (Robisoa et al. 2008). According to Cameron (2002), a forest stand is considered stable when the H/D ratio is less than 100 of early selective thinning.

The evaluation of competition between trees for light requires the study on the extent of crown cover, as well as the stability coefficient of the stems (SC). This parameter was estimated by projecting a quadrilateral on the ground, one of the diagonals of which was the axis corresponding to the maximum length of the crown and the second was perpendicular to the first axis. The two diagonals were cut at the foot of the tree. The area of this quadrilateral (Q) was then calculated from the two measured lengths:

$$
Q=1 / 2 *(L a+L b) *(l a+l b)
$$

Where: $L a+L b$ is first axis (maximum length of the crown) and $l a+l b$ is second axis (perpendicular to the first axis). Correlations between the crown surface and the stability factor (SC) were calculated using Excel 2010.

\section{Assessment of the health of forest plots}

The assessment of the crown condition by specific protocols makes it possible to characterize the stages of decline of each individual observed (Gauquelin 2010). In order to characterize the health status of Sidi R'Ghies stands, the DEPEFEU, DEPERIS and ICP forests protocols were used to assess the condition of hardwood and softwood/coniferous crown trees. As the season does not allow the use of all the criteria proposed by Nageleisen (2010), the criteria represented in Table 1 were used.

The hardwood dieback protocol (DEPEFEU) is used to assess the dieback of hardwood forests based on a multicriteria description of the crown (Nageleisen 2010). It is based on the observation from the soil of symptoms giving information on the crown health status. Three symptomatological criteria can be distinguished: crown transparency, mortality of perennial organs (branches, twigs) and leaf mass distribution. Each of these symptom categories is divided into sub-categories (Table 1), symptomatological criteria to be observed in the upper crown of trees (adult trees of the dominant stage) in order to make a dieback rating.

The tree dieback method (DEPERIS) is based on two perennial symptomatological criteria that describe the appearance of tree crowns: branch mortality and absence of ramification (or absence of needles for softwood). These two notes are complementary (Vallet et al. 2006).

The objective of ICP Forests (protocol conceived within the framework of the International Cooperative Programme on Forests) is to evaluate different criteria such as defoliation, discoloration, fruiting, damage, and symptoms in order to estimate the vitality of the tree. For each tree, three types of observations are made: (i) description of the observation conditions (visibility, competition, and social status), (ii) assessment of crown condition and (iii) description of damage (Eichhorn et al. 2005).

In order to limit the interference between phytosanitary problems and symptoms related to competition or lack of light, the sample trees were taken into account the dominant or codominant. These trees should be observed from several points (at least two), if possible in lateral view from a distance equivalent to the total height of the tree. Observations were made in bright daylight, avoiding hours that were too late (or too early) during which the light was modified (dominant red or blue) and did not allow correct observations of certain criteria (abnormal coloration in particular). The use of binoculars was generally useful for refining observations.

\section{Method for scoring a crown criterion}

The appearance of the crown cover was assessed by assigning a qualitative score of 0 to 5 to the selected criteria (Table 2), which may correspond to intensity (e.g. transparency), a number (e.g. window), a frequency (e.g. dead branches). The percentage of class limits are only indicative and are especially useful for the assessment of foliar.

\section{Simplified tree crown appearance assessment (DEPERIS protocol).}

The combination of 2 criteria (branch mortality and absence of ramification) makes it possible to define a synthetic DEPERIS withering score, calculated as follows:

$$
\text { DEPERIS }=[((5-\mathrm{MB}) / 5) * \mathrm{MR} \text { or MA })]+\mathrm{MB}
$$

Where: $\mathrm{MB}$ is branch mortality, MR is ramification mortality and MA is mortality of needles for softwood 
Table 1. DEPEFEU protocol for hardwood and coniferous trees (Nageleisen 2010)

\begin{tabular}{|c|c|c|}
\hline Classes & Hardwood & Softwood/coniferous \\
\hline 0 & No symptoms & $\begin{array}{l}\text { No symptoms: well-developed crown, secondary branches } \\
\text { and no dead branches in the upper part of the crown. }\end{array}$ \\
\hline 1 & $\begin{array}{l}\text { Fine, dried branches in the periphery of the crown. Secondary } \\
\text { branches developed. }\end{array}$ & $\begin{array}{l}\text { Fine, dried branches in the periphery of the crown. } \\
\text { Secondary branches not very abundant. }\end{array}$ \\
\hline 2 & $\begin{array}{l}\text { Branches dried out in the upper half of the crown, dead } \\
\text { branches present, but representing less than } 50 \% \text { of the } \\
\text { crown. Secondary branches not very developed. }\end{array}$ & $\begin{array}{l}\text { Dead branches in the upper half of the crown but } \\
\text { representing less than 50\% of the crown. Cut crown. }\end{array}$ \\
\hline 3 & Dead branches making up more than $50 \%$ of the crown. & $\begin{array}{l}\text { Dead branches making up more than } 50 \% \text { of the } \\
\text { crown. Few ramifications. }\end{array}$ \\
\hline 4 & Dead crown & Dead crown \\
\hline
\end{tabular}

Table 2. Notations used for the DEPEFEU method (Nageleisen 2010)

\begin{tabular}{|c|c|c|c|c|}
\hline Note & Intensity & Frequency & Number & Indicative $(\%)$ \\
\hline 0 & Absence or trace & None to very low & 0 to a few rare & $0-5$ \\
\hline 1 & Low & Low & A few to a small number & $6-25$ \\
\hline 2 & Somewhat strong & Moderate & Somewhat numerous & $26-50$ \\
\hline 3 & Strong & Important & Many & $51-75$ \\
\hline 4 & Very strong & Very important & Very numerous & $76-95$ \\
\hline 5 & Total & The entire rated party concerned & Total & $96-100$ \\
\hline M & \multicolumn{4}{|c|}{ Totally dead tree, i.e. whose cambium died at breast height. } \\
\hline NO & Tree not observed & fy the reason in remarks. & & \\
\hline
\end{tabular}

Table 3. Synthetic dieback score using DEPERIS protocol

\begin{tabular}{llllllll}
\hline \multicolumn{7}{c}{$\begin{array}{l}\text { Lack of ramifications (hardwoods) } \\
\text { Lack of needles (softwood) }\end{array}$} & \\
\hline Branch & & 0 & 1 & 2 & 3 & 4 & 5 \\
mortalities & 0 & A & B & C & D & E & F \\
& 1 & B & B & C & D & E & F \\
& 2 & C & C & D & D & E & F \\
& 3 & D & D & D & E & F & F \\
& 4 & E & E & E & F & F & F \\
& 5 & F & F & F & F & F & F \\
\hline
\end{tabular}

It is also possible to use the following chart to assign the overall DEPERIS score (Table 3). A dying tree is that within $\mathrm{D}, \mathrm{E}$ and $\mathrm{F}$ code, and a dying stand is that of more than $20 \%$ of dying trees.

\section{The ICP method}

The protocol was developed as part of the International Cooperative Programme on Forests (ICP Forests). For each of the trees, three types of observations were made: (i) a description of the observation conditions, (ii) an assessment of the crown condition and (iii) a description of the damage (Eichhorn et al. 2010). In this study, the conditions of observation included: (i) Visibility: it corresponds to the conditions under which the assessable crown can be seen from the ground (Braem 2009), ranged from 1 (fully visible crown) to 4 (not visible crown); (ii) Social status: it is a relative measure of the size and place of a tree in relation to the surrounding trees (Braem 2009), ranged from 1 (dominant: or free-growing tree) to 4 (dominated: trees largely overtaken by others and not receiving any direct light): (iii) Shading index (Competition): it is an indication of the space available for crown development and reflects the local closure of the canopy by assessing the number of sides of the crown in contact with other peaks, ranged from 1 (free growth) to 5 (crown affected by four sides). Understorey trees are excluded from this sample (Braem 2009).

\section{RESULTS AND DISCUSSION}

The definition of forest health is a fairly ambiguous concept, but it is generally a more or less subjective human interpretation based on a comparison with the "normal" state of tree crown under specific ecological conditions (Barthelemy and Caraglio 2007; Toïgo et al. 2015). As a result, a healthy forest is characterized by the fact that it does not show signs of decline regardless of external stresses. Forest health is threatened by factors such as pathogens, climate change, pollution, invasive species and uncontrolled game populations (Helama et al. 2009).

The permanent monitoring of the health status in the forest requires a twofold approach: (i) visual observation from the ground and (ii) remote sensing observation (Braem 2009). In our case in the Sidi R'Ghies forest area, we chose the first approach using specific protocols (i.e. 
DEPEFEU, DEPERIS and ICP Forests) because it is a simple, quick and comprehensive method of assessing the health of the forest. This approach is also objective because it can be repeated annually in the future. The field approach makes it possible to observe, at the scale of the individual tree, a large number of parameters reflecting the state of health. These variables can then be related to other vitality indicators such as foliar nutritional status and circumferential increase. Visual observation also reveals relatively low levels of defoliation or discoloration, observes the types of symptoms and identifies the agents responsible (Misson et al. 2010; Braem 2011).

\section{Stand species composition}

In the softwood plots, the main species in terms of number of individuals was Aleppo pine, which constituted $98 \%$ of all trees observed, followed by cypress in a much smaller proportion $(2 \%)$. In the hardwood plots, the most abundant species was the holm oak, which accounted for $60 \%$ of the population studied, followed by Aleppo pine (26\%) and cypress (7\%). Juniper and olive trees were only anecdotally found in plot 5 (3\% and $4 \%$ respectively). These plots represented higher biodiversity than the softwood plots. The average density and basal area values of Aleppo pine $(325 \pm 55$ individuals/ha and $10.12 \pm$ $1.69 \mathrm{~m}^{2} / \mathrm{ha}$ ) were higher than those of holm oak, which were $238 \pm 23$ individuals/ha and $1.25 \pm 0.09 \mathrm{~m}^{2}$ respectively.

\section{Stand structure based on diameter and height}

The diameter of the sample trees in the plots studied is presented in Figure 2. The majority of Aleppo pine belong to class $3(20-30 \mathrm{~cm})$ with a rate of $32.82 \%$. In second place are classes $2(10-20 \mathrm{~cm}), 1(0-10 \mathrm{~cm})$ and $4(>30 \mathrm{~cm})$ with a respective percentage varying between $25.19 \%, 22.90 \%$ and $19.08 \%$. These 4 categories represent young trees.

In holm oak, classes $1(0-5 \mathrm{~cm})$ and $2(5-10 \mathrm{~cm})$ make up the majority of the population and vary between $27.08 \%$, $56.25 \%$; while the classes 3 and 4 have a relatively low cumulative percentage with $12.5 \%$ and $4.17 \%$, respectively (Figure 2). Based on these results, the Aleppo pine and holm oak stands can be regarded as very young.

The measurements of the tree height are presented in Figure 3. Class $4(>15 \mathrm{~m})$ is the most dominant with $33.07 \%$ for Aleppo pine, followed by class $2(5-10 \mathrm{~m})$ while classes 1 and 3 are less represented. In holm oak, the dominant class is class 3 , with $30.63 \%$ of the trees observed. The fourth class is less important than the previous one with a percentage of $26.12 \%$; while the two remaining classes are less frequented (21.62\%).

\section{Health status based on the appearance of the crown trees (DEPEFEU class)}

DEPEFEU class was used to assess health status of the two groups of plot studied (i.e. Aleppo pine and holm oak) based on the appearance of the crown trees. In the Aleppo pine plots, the result indicates that the majority of the trees are in classes 3 and 2 with proportion of $33.33 \%$ and $29.46 \%$, respectively (Figure 4). A smaller proportion of trees are in classes 1 and $4(18.33 \%$ and $11.63 \%$ respectively), and the percentage of trees in class 0 is the smallest $(6.97 \%)$. Plot 2 within the group of Aleppo pine is characterized by the highest rate of healthy trees $(9.38 \%)$ where symptoms are completely absent; while the tree crown of plot 3 is declining and shows $16 \%$. The majority of trees are classified in classes 2 and 3 . The percentage of these trees is quite high, since they represent $62.78 \%$ of all trees in the sampled plots. In summary, the health status of Aleppo pine is estimated at a fairly average level, despite the negligible presence of dead standing trees.

In the holm oak plots, it can be seen that the majority of the trees are classified in class 2 with a percentage of $44.79 \%$ followed by class 3 with $28.12 \%$ (Figure 4 ). The proportion of oaks that have a very satisfactory condition from the point of view of crown appearance (class 0) is $15.62 \%$. Therefore, the health status of this species is quite good because the presence of declining trees is relatively low.

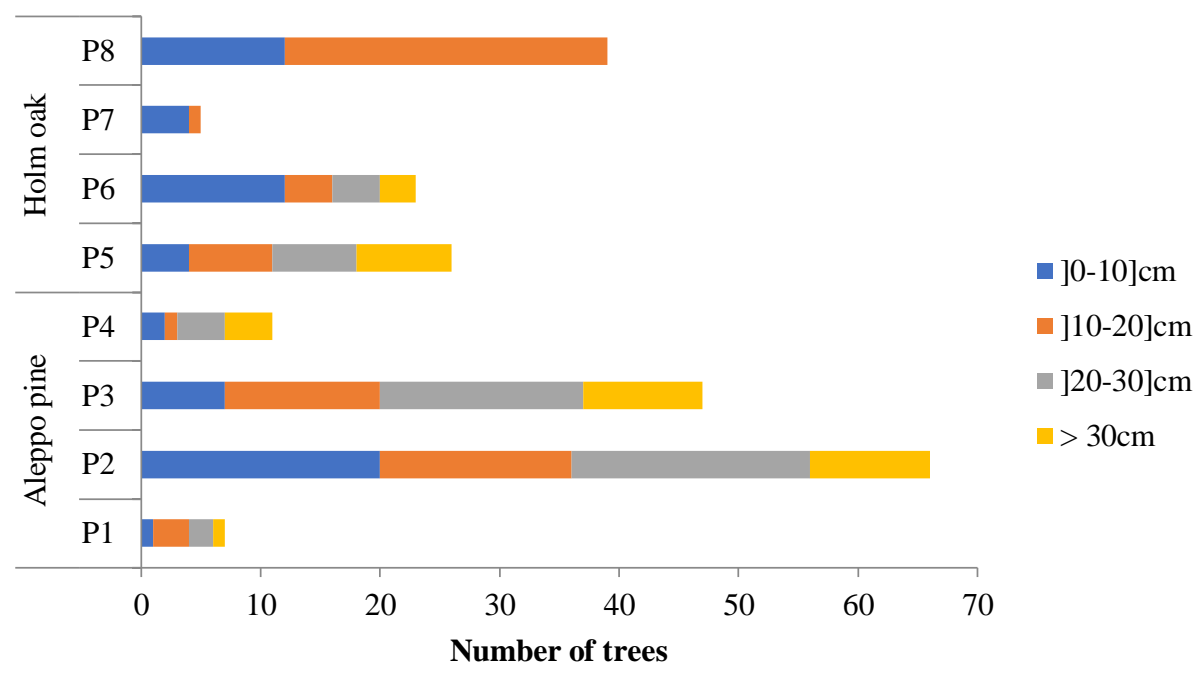

Figure 2. Distribution of Aleppo pine and holm oak by diameter classes 


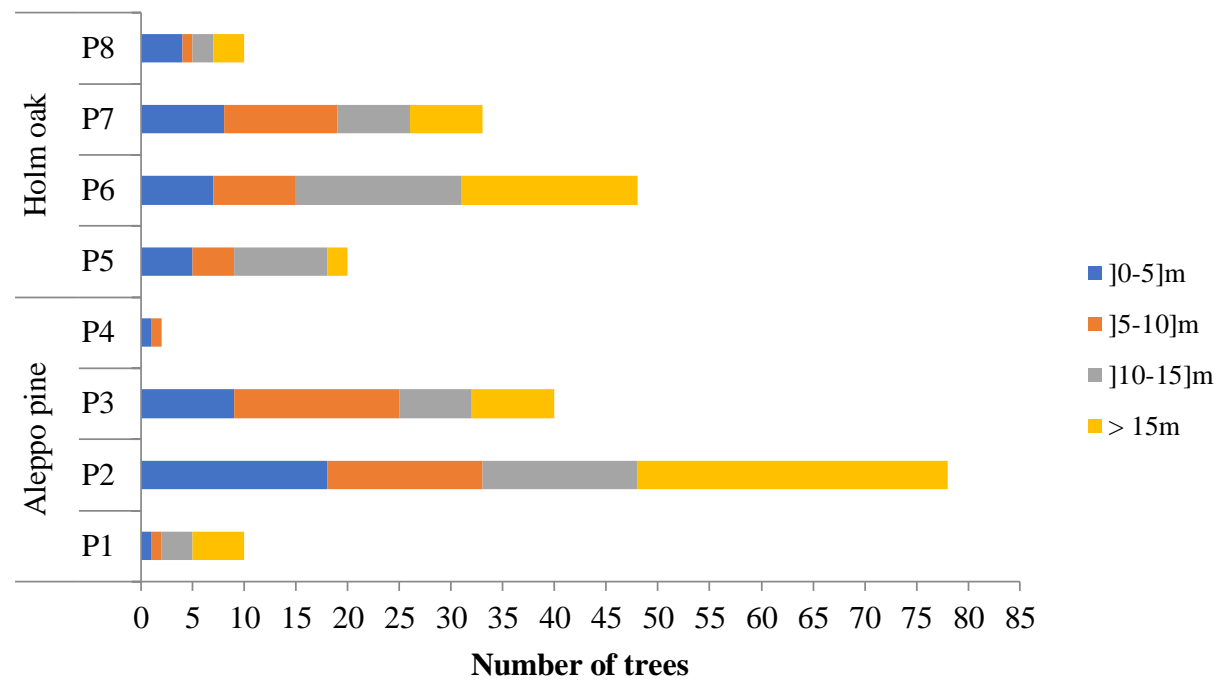

Figure 3. Distribution of Aleppo pine and holm oak by height classes

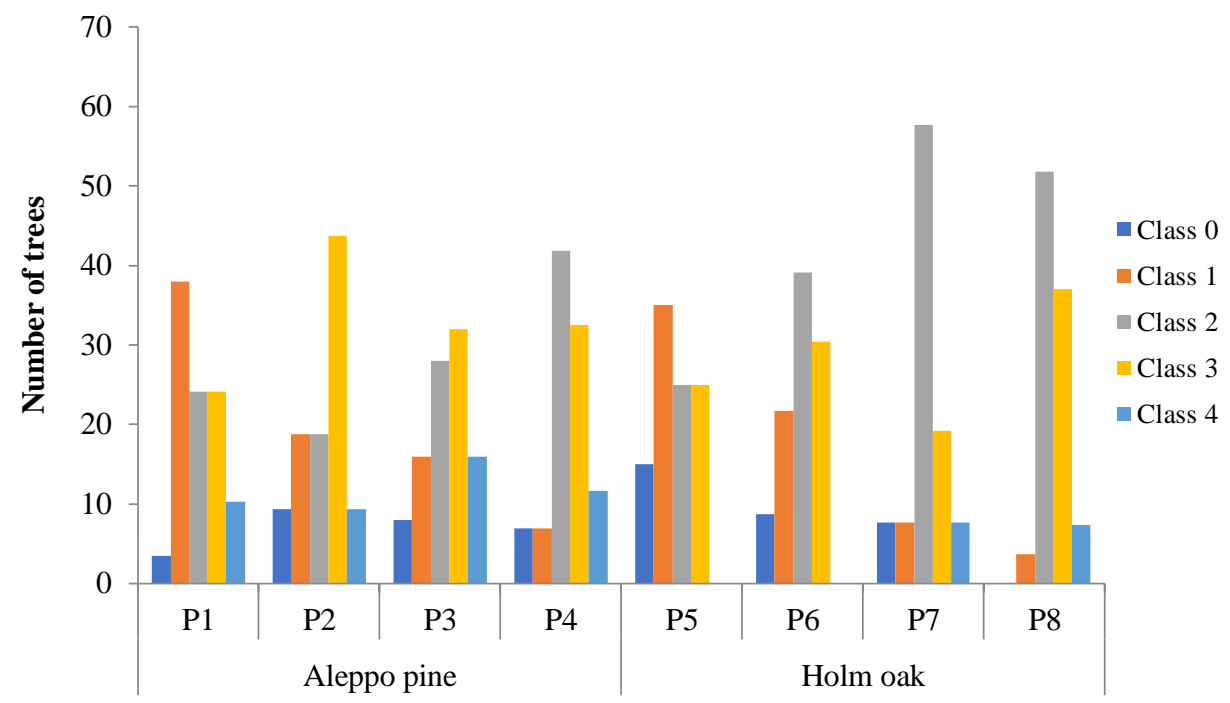

Figure 4. Health status of the plots studied, i.e. Aleppo pine (plots 1-4) and holm oak (plots 5-8), based on the appearance of the crown trees (DEPEFEU class)

\section{Health status based on the DEPEFEU index value}

All the plots of Aleppo pine and two plots of holm oak (i.e. plots 7 and 8) have fairly high DEPEFEU values, ranging from 2 to 2.48 (Table 4 ). This means that they have the most pronounced decline. The DEPEFEU index values of plots 5 and 6 (i.e. 1.6 and 1.9, respectively) indicate an average decline in holm oak. All the results obtained from the DEPEFEU index value indicate that the health status of Aleppo pine is poor (Table 4). This can be explained by the notation used, which took into account all dry branches, which is not adapted to the appearance of the pine and also the soils seem to be more unfavorable to dying trees (Anderegg and al. 2014). On the other hand, our results contrast with those of Dobbertin (2005), where the crown condition is generally good in both coniferous and deciduous trees in the Paimpont forest. Through the evaluation of height and diameter, the H/D ratio was calculated, which will be the competition and wind resistance index of the trees (Table 4). Indeed, when this ratio is close to 60 , the trees are stable against the wind and competition between them is low. If it is 100 or more, the competition is too high and they may not be able to withstand strong winds.

\section{Health status based on the DEPERIS index}

Based on analysis using DEPERIS index, the result indicates that the majority of pines and oaks are declining, representing $85.27 \%$ and $77.08 \%$ of the Aleppo pine and 
holm oak population, respectively, while the healthy crown trees represent $14.73 \%$ for the pine and $22.92 \%$ for the oak (Figure 5).

\section{Correlations of crown area and stability factor (SC)}

The shape of the projection area of the crown tops of dominant trees can give indications of competition between crown tops. It is considered that when one of the axes relative to the trunk of the projection area is less than $2 \mathrm{~m}$ long, the crown is unbalanced (Poot and Veneklaas 2012). Table 5 shows a negative correlation between the slenderness coefficient and crown area $\left(\mathrm{R}^{2}=0.5347\right)$ observed for Aleppo pine plot 2. This correlation, therefore, means that the larger the crown area, the lower the slenderness coefficient. However, as observed in plots 1,3 and 4 , the correlation is not significant $\left(R^{2}=0.0237\right.$, $\mathrm{R}^{2}=0.0392$ and $\left.\mathrm{R}^{2}=0.2096\right)$. The correlation is also negative for $\mathrm{P} 5, \mathrm{P} 6$, and $\mathrm{P} 8$, while it is positive for $\mathrm{P} 7$. Whatever the $\mathrm{R}^{2}$ values obtained, this correlation is not significant for all holm oak plots.

According to the shape of the projection area of the oak trees on the ground, the imbalance of the oak trees is greater than that of the pines. This observation could be related to the fact that the pines were grouped at certain positions where they were more concentrated. In addition, the analysis of slenderness coefficients shows that in Aleppo pine plots, the crown area appears to be negatively correlated with the slenderness coefficient. We assume that trees that cannot spread their branches across their widths try to grow as high as possible to capture as much radiation as possible. With the exception of Aleppo pine plot, $2\left(\mathrm{R}^{2}=\right.$ $0.534)$ where the linear regression is significant; the linear regression calculated for the rest of the Aleppo pine and
Holm oak plots has a low coefficient, which means that the explanatory power of the slenderness coefficient by the crown area is low.

Table 4. Summary table of dendrometric parameters and DEPEFEU index value of the two groups of plot studied (i.e. Aleppo pine and holm oak)

\begin{tabular}{lccccc}
\hline Species & Plots & D $(\mathbf{c m})$ & H $(\mathbf{m})$ & H/D & DEPEFEU \\
\hline Aleppo pine & P1 & $20 \pm 2.48$ & $9.04 \pm 1.04$ & 48.72 & 2 \\
& P2 & $18 \pm 4.10$ & $10.3 \pm 1.66$ & 60.39 & 2.25 \\
& P3 & $22 \pm 4.63$ & $8.51 \pm 2.10$ & 40.48 & 2.32 \\
Holm oak & P4 & $20 \pm 5.97$ & $8.13 \pm 1.89$ & 41.99 & 2.34 \\
& P5 & $8.0 \pm 1.30$ & $4.68 \pm 1.10$ & 74.08 & 1.6 \\
& P6 & $8.9 \pm 1.55$ & $4.05 \pm 2.10$ & 56.52 & 1.91 \\
& P7 & $7.8 \pm 1.75$ & $3.91 \pm 1.90$ & 61.63 & 2.12 \\
& P8 & $7.6 \pm 1.40$ & $3.96 \pm 1.42$ & 75.63 & 2.48 \\
\hline
\end{tabular}

Table 5. Correlations of crown area and stability factor (SC)

\begin{tabular}{llll}
\hline Plots & Measures & Regression equation & $\mathbf{R}^{\mathbf{2}}$ \\
\hline \multicolumn{2}{l}{ Aleppo pine } & & \\
P1 & Crown area /CE & $\mathrm{y}=-0.453+59.014$ & 0.0237 \\
P2 & Crown area /CE & $\mathrm{y}=-4513+106.92$ & 0.5347 \\
P3 & Crown area /CE & $\mathrm{y}=0.4473 \mathrm{x}+39.919$ & 0.0392 \\
P4 & Crown area /CE & $\mathrm{y}=-1.186 \mathrm{x}+62.413$ & 0.2096 \\
Holm oak & & \\
P5 & Crown area /CE & $\mathrm{y}=-3.0838+108.6$ & 0.0805 \\
P6 & Crown area /CE & $\mathrm{y}=-2.777 \mathrm{x}+76.87$ & 0.3120 \\
P7 & Crown area /CE & $\mathrm{y}=3.6897 \mathrm{x}+48.338$ & 0.0260 \\
P8 & Crown area /CE & $\mathrm{y}=-6.746 \mathrm{x}+107.01$ & 0.0962 \\
\hline
\end{tabular}

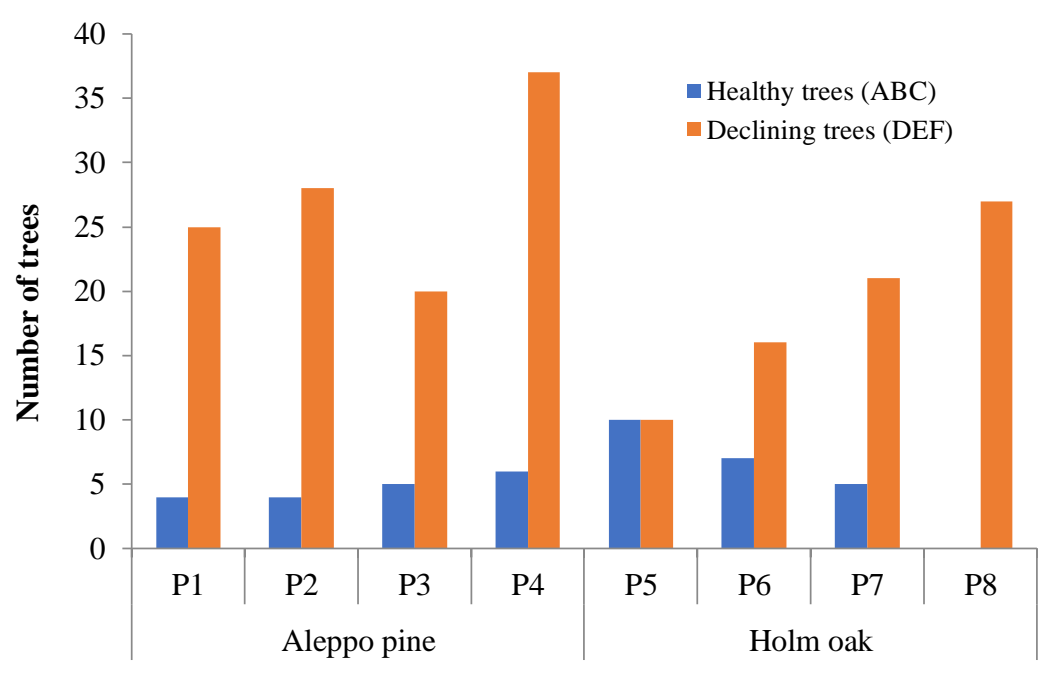

Figure 5. Health status of the plots studied, i.e. Aleppo pine (plots 1-4) and holm oak (plots 5-8), based on the DEPERIS index. 


\section{Health status based on the ICP Forests}

Visibility is a limiting factor and a source of error for crown characterization. In fact, when the visibility of the crown is reduced because of competing for crown tops, the observable portion is extrapolated to the entire crown. In some cases of non-visibility, observers abstained from any ratings for defoliation, discoloration and observable fruiting (Ostry et al. 2011).

The results obtained indicate that $78.46 \%$ of Aleppo pines and $55.20 \%$ of holm oaks have a fully visible crown. Tops are partially visible for $19.23 \%$ of pines and $27.03 \%$ of oaks. The remaining parts of the oaks have back-lit canopies $(14.58 \%)$. The tighter a tree is between its neighbors, the lower the visibility. In dense stands, where crowns are entangled, it becomes very difficult to see the upper part of the crown (Braem 2011). It can be deduced that almost all of the Aleppo pine trees and two holm oak plots are in a thinning form.

Social status is a relative measure of the position a tree occupies in relation to the surrounding trees (VicenteSerrano et al. 2010). Knowing social status makes it possible to better interpret the condition of a tree's crown. The social status of a tree depends on many factors: competition from neighboring trees, silviculture (thinning, regeneration), stationary conditions and genetics of the tree itself (Garber and Maguire 2005). The results show that the majority of the trees are dominant or co-dominant with observed trees with $31.41 \%$ and $39.27 \%$, respectively. Nearly $20.42 \%$ of the pines are subdominant and (8.9\%) are dominated. In the holm oak plots, half is co-dominant Nearly $34.37 \%$ of oaks are dominant; $10.42 \%$ are subdominant and the dominated represent the lowest percentage (5.2\%). According to Braem (2009), dominant trees are assumed to be more sensitive to stress than codominant trees, better inserted into the canopy mass. From these results, we can say that nearly a third of the pines and oaks in the 8 plots are supposed to be more sensitive to stress, while $2 / 3$ of the trees are less sensitive.

According to the standard protocol, competition is defined as the space available for crown development. It is measured in six levels (from "crown touched on one side" to "crown touched on four sides", plus "free growth" (single tree). This index reflects the degree of closure around the tree (Pontius and Hallett 2014). The majority of pines have two or three sides of their crown in contact with other crowns, respectively $37.5 \%$ and $44.79 \%$ of the population, and the more competitive crown tops (four sides) represent $9.38 \%$ of cases. For holm oak, the majority of trees are highly competitive $(35.41 \%$ on both sides and $45.83 \%$ on all three sides). Only $2.08 \%$ of oaks grow without constraints.

A relationship between dieback and available crown space has already been observed by Eichhorn et al. (2005). It can be assumed that less competitive trees are more subject to environmental factors (wind, falling neighboring trees, pests, etc.) (Seidling 1999; Mace et al. 2012).

To conclude, the sustainability of a forest ecosystem is closely linked to its health. The diagnosis of the health status of Aleppo pine and holm oak stands in the Sidi $\mathrm{R}^{\prime}$ Ghies forest is based on field observation of individuals of each species and on three methods: DEPEFEU, DEPERIS, and ICP Forests. The interest of this study is the characterization of the forest stands of this forest. However, the comparison remains difficult because the dominant species on the plots studied is not the same (a hardwood: holm oak and softwood: Aleppo pine). The sanitary state of different plots was average, which shows that Pinus halepensis, an indigenous species, is well adapted to the region. Its density is higher than oak, it is of great economic interest, which explains its introduction and abundance in Algeria. On the other hand, the biodiversity carrying capacity is medium to low and needs to be improved. The holm oak has the advantage of not impoverishing the soil and is a stand with both cultural and ecological heritage interests. The plots studied are therefore linked to two opposing objectives: on the one hand economic interest and on the other hand the conservation of social and natural heritage. A study such as this one can be an appropriate complementary management tool for foresters in Algeria.

\section{REFERENCES}

Anderegg WRL, Anderegg LDL, Berry JA, Field CB, 2014. Loss of whole-tree hydraulic conductance during severe drought and multiyear forest die-off. Oecologia 175: 11-23.

Barthelemy D, Caraglio Y. 2007. Plant architecture: a dynamic, multilevel and comprehensive approach to plant form, structure, and ontogeny. Ann Bot 99 (3): 375-407.

Belloula S, Beghami Y. 2018. Assessment of the Dynamics of Atlas Cedar Decline (Cedrus atlantica Manetti) by Remote Sensing in the Aurès area, Algeria. Arab World Geogr 21 (2-3): 154-167.

Braem S. 2009. Suivi de l'état sanitaire en Forêt de Soignes bruxelloise. Rapport complet. [France]

Braem S. 2011. Suivi de l'état sanitaire en Forêt de Soignes bruxelloise. Rapport complet. [France]

Cameron AD. 2002. Importance of early selective thinning in the development of long-term stand stability and improved log quality: A review. Forestry 75: 25-35.

Cater M. 2015. A 20-year overview of Quercus robur L. mortality and crown conditions in Slovenia. Forests 6 (3): 581-593.

Dobbertin M. 2005. Tree growth as indicator of tree vitality and of tree reaction to environmental stress: a review. Crown defoliation improves tree mortality models. Eur J For Res 124: 319-333.

Delaporte A, Zanella A, Vincenta G, Bugeata M, Damesina C, Bazota C. 2017. Structural and functional differences in the belowground compartment of healthy and declining beech trees. Appl Soil Ecol 117-118: 106-116.

Denman S, Brown N, Kirk S, Jeger M, Webber J. 2014. A description of the symptoms of acute oak decline in Britain and a comparative review on causes of similar disorders on oak in Europe. Forestry 87 (4): 535-551.

Eickenscheidt N, Wellbrock N. 2014. Consistency of defoliation data of the national training courses for the forest condition survey in Germany from 1992 to 2012. Environ Monit Assess 186 (1): 257-275.

Eichhorn J, Icke R, Isenberg A, Paar U, Schonfelder E. 2005. Temporal development of crown condition of beech and oak as a response variable for integrated evaluations. Eur J For Rese 124: 335-347.

Galiano L, Martinez-Vilalta J, Sabate S, Lloret F. 2012. Determinants of drought effects on crown condition and their relationship with depletion of carbon reserves in a Mediterranean holm oak forest. Tree Physiol 32 (4): 478-489.

Garber SM, Maguire DA. 2005. The response of vertical foliage distribution to spacing and species composition in mixed conifer stands in central Oregon. For Ecol Manag 211 (3): 341-355.

Gauquelin X. 2010. Guide de gestion des forêts en crise sanitaire. [France] 
Gerard B, Bréda N. 2014. Radial distribution of carbohydrate reserves in the trunk of declining European beech trees (Fagus sylvatica L.). Ann For Sci 71 (6): 675-682.

Girard F, Vennetier M, Ouarmim S, Caraglio Y, Misson L. 2011. Polycyclism, a fundamental tree growth process, decline with recent climate change: the example of Pinus halepensis Mill. in Mediterranean France. Trees 25 (2): 311-322.

Gricar J, De Luis M, Hafner P, Levani T. 2013. Anatomical characteristics and hydrologic signals in tree-rings of oaks (Quercus robur L.). Trees-Struct Funct 27 (6): 1669-1680.

Gustafson EJ, Sturtevant BR. 2013. Modeling forest mortality caused by drought stress: Implications for climate change. Ecosystems 16 (1): 60-74.

Helama S, Laanelaid A, Raisio J, Tuomenvirta H. 2009. Oak decline in Helsinki portrayed by tree-rings, climate and soil data. Plant Soil 319 (1-2): 163-174

Helama S, Laanelaid A, Raisio J, Makela HM, Hilasvuori E, Jungner H, Sonninen E. 2014. Oak decline analyzed using intraannual radial growth indices, delta $\mathrm{C}-13$ series and climate data from a rural hemiboreal landscape in southwesternmost Finland. Environ Monit Assess 186 (8): 4697-4708.

Hicke JA, Logan JA, Powell J, Ojima DS. 2006. Changing temperatures influence suitability for modelled mountain pine beetle (Dendroctonus ponderosae) outbreaks in the western United States. J Geophys Res 111: 1-12. DOI: 10.1029/2005JG000101.

Keča N, Koufakis I, Dietershagen J, Nowakowska JA, Oszako T. 2016 European oak decline phenomenon in relation to climatic changes. Folia Forestalia Polonica, Ser A-For 58 (3): 170-177.

Keenan RJ, Reams GA, Achard F, De Freitas JV, Grainger A, Lindquis E. 2015. Dynamics of global forest area: results from the FAO Global Forest Resources Assessment 2015. For Ecol Manag 352: 9-20.

Klein T, DiMatteo G, Rotenberg E, Cohen S, Yakir D. 2013. Differential ecophysiological response of a major Mediterranean pine species across a climatic gradient. Tree Physiol 33 (1): 26-36.

Lee CA, Voelker S, Holdo RM, Muzika RM. 2014. Tree architecture as a predictor of growth and mortality after an episode of red oak decline in the Ozark Highlands of Missouri, USA. Can J For Res 44 (9): $1005-1012$

Linares JC, Taïqui L, Camarero JJ. 2011. Increasing drought sensitivity and decline of Atlas cedar (Cedrus atlantica) in the Moroccan Middle Atlas forests. Forests 2 (3): 777-796.

Lindner M, Maroschek M, Netherer S, Kremer A, Barbati A, GarciaGonzalo J, Seidl R, Delzon S, Corona P, Kolström M, Lexer MJ, Marchetti M. 2010. Climate change impacts, adaptive capacity, and vulnerability of European forest ecosystems. For Ecol Manag 259: 698-709.

Mace GM, Norris K, Fitter AH. 2012. Biodiversity and ecosystem services: A multilayered relationship. Trends Ecol Evol 27 (1): 19-25.

Martinez-Vilalta J, Lloret F, Breshears DD. 2012. Drought-induced forest decline: causes, scope and implications. Biol Lett 8 (5): 689-691.

Michelot A, Simard S, Rathgeber C, Dufrene E, Damesin C. 2012. Comparing the intra-annual wood formation of three European species (Fagus sylvatica, Ouercus petraea and Pinus sylvestris) as related to leaf phenology and non-structural carbohydrate dynamics. Tree Physiol 32 (8): 1033-1045.

Misson L, Limousin JM, Rodriguez R, Letts MG. 2010. Leaf physiological responses to extreme droughts in Mediterranean Quercus ilex forest. Plant Cell Environ 33 (11): 1898-1910.

Moorcroft PR, Pacala SW, Lewis MA. 2006. Potential role of natural enemies during tree range expansions following climate change. J Theor Biol 241 (3): 601-616. DOI: 10.1016/j.jtbi.2005.12.019.

Morcillo L, Gallego D, González E, Alberto Vilagrosa A. 2019. Forest decline triggered by phloem parasitism-related biotic factors in Aleppo pine (Pinus halepensis). Forests 10 (8): 2-18.

Nageleisen LM. 2010. Quelques Indicateurs de la Santé des Forêts Françaises. Paris. [France]

Nageleisen LM. 2011. Manuel de Notation des dommages forestiers (symptômes, causes, état des cimes). Paris. [France]
Niu SL, Luo YQ, Li DJ, Cao SH, Xia JY, Li JW, Smith MD. 2014. Plant growth and mortality under climatic extremes: An overview. Environ Exp Bot 98: 13-19.

Ostry M, Venette R, Juzwik J. 2011. Decline as a disease category: Is it helpful? Phytopathology 101 (4): 404-409.

Petit JP, Hampe A, Cheddadi R. 2005. Climate changes and tree phylogeography in the Mediterranean. Taxon 54 (4): 877-885.

Pontius J, Hallett R. 2014. Comprehensive methods for earlier detection and monitoring of forest decline. For Sci 60 (6): 1156-1163.

Poot P, Veneklaas EJ. 2012. Species distribution and crown decline are associated with contrasting water relations in four common sympatric eucalypt species in southwestern Australia. Plant Soil 364: 409-423.

Rached-Kanouni M, Alatou D, Sakr S. 2012. Responses of cork oak seedlings to short-term exposures to low temperatures. Am J Sci Res 59: $28-41$.

Raffa KF, Aukema BH, Bentz BJ, Carroll AL, Hicke JA, Turner MG, Romme WH. 2008. Cross-scale drivers of natural disturbances prone to anthropogenic amplification: the dynamics of bark beetle eruptions. Bioscience 58 (6): 501-517.

Robisoa M, Rajoelison G, Rabenilalana M, Rakoto H. 2008. Définition d'un état zéro et mise en place d'un système de suivi écologique permanent de l'Arboretum de la station forestière de Mandraka. Centre for development and environment (cde). ESAPP-Eastern and Southern Africa Partnership Program.

Rosas T, Galiano L, Ogaya R, Penuelas J, Martinez-Vilalta J. 2013. Dynamics of non-structural carbohydrates in three Mediterranean woody species following long-term experimental drought. Front Plant Sci 4: 1-16.

Seidling W. 1999. Räumliche Struktureiner subspontanen Population von Taxus baccata, Jungpflanzen. Flora 194: 439-451.

Terrab A, Paun O, Talavera S, Tremetsberger K, Arista M, Stuessy TF. 2006. Genetic diversity and population structure in natural populations of Moroccan Atlas cedar (Cedrus atlantica; Pinacea) determined with cpSSR markers. Am J Bot 93: 1274-1280.

Thabeet A, Vennetier M, Gadbin-Henry C, Denelle N, Roux M, Caraglio Y, Vila B. 2009. Response of Pinus sylvestris L. to recent climatic events in the French Mediterranean region. Trees Struct Funct 23 (4): 843-853.

Thomas FM, Blank R, Hartmann G. 2002. Abiotic and biotic factors and their interactions as causes of oak decline in Central Europe. For Pathol 3: 277-307.

Thuiller W, Brotons L, Araujo MB, Lavorel S. 2004. Effects of restricting environmental range of data to project current and future species distributions. Ecography 27: 165-172

Tö̈go M, Vallet P, Perot T, Bontemps JD, Piedallu C, Courbaud B. 2015. Overyielding in mixed forests decreases with site productivity. J Ecol 103 (2): 502-512.

Touhami I, Chirino E, Aouinti H, Khorchani A, Elaieb MT, Khaldi A Nasr Z. 2019. Decline and dieback of cork oak (Quercus suber L.) forests in the Mediterranean basin: a case study of Kroumirie, Northwest Tunisia. J For Res 28 (3): 1-17.

Tulik M. 2014. The anatomical traits of trunk wood and their relevance to oak (Quercus robur L.) vitality. Eur J For Res 133 (5): 845-855.

Vallet P, Dhôte JF, Le Moguedec G, Ravart M, Pignard G. 2006. Development of total aboveground volume equations for seven important forest species in France. For Ecol Manag 229 (1-3): 98-110.

Vicente-Serrano SM, Lasanta T, Gracia C. 2010. Aridification determines changes in forest growth in Pinus halepensis forests under semiarid Mediterranean climate conditions. Agric For Meteorol 150 (4): 614 628.

Vitale M, Proietti C, Cionni I, Fischer R, De Marco A. 2014. Random forests analysis: A useful tool for defining the relative importance of environmental conditions on crown defoliation. Water Air Soil Pollut 225 (6): 1-17.

Woo SY. 2009. Forest decline of the world: A linkage with air pollution and global warming. Afr J Biotechnol 8 (25): 7409-7414. 